\title{
Computational Notes on The Effect of (Li-Na-K) on Calcium Zinc Phosphate Oxide Glasses
}

\author{
Medhtat A. Ibrahim ${ }^{1(D)}$, Hend A. Ezzat ${ }^{2}$ (D), Fanli Meng ${ }^{3}$, Ibrahim S. Yahia 4, 5, 6 (D), \\ Heba Y. Zahran ${ }^{4,5,6}$, Hanan Elhaes 7 (D) \\ 1 Molecular Spectroscopy and Modeling Unit, Spectroscopy Department, National Research Centre, 33 El-Bohouth Str. \\ 12622 Dokki, Giza, Egypt \\ 2 Nano Technology Unit, Solar and Space Research Department, National Research Institute of Astronomy and Geophysics \\ (Nano NRIAG), 11731 Helwan, Cairo, Egypt \\ 3 College of Information Science and Engineering, Northeastern University, Shenyang 110819, China \\ 4 Research Center for Advanced Materials Science (RCAMS), King Khalid University, Abha 61413, P.O. Box 9004, Saudi \\ Arabia \\ 5 Advanced Functional Materials \& Optoelectronic Laboratory (AFMOL), Department of Physics, Faculty of Science, King \\ Khalid University, P.O. Box 9004, Abha, Saudi Arabia \\ 6 Nanoscience Laboratory for Environmental and Bio-Medical Applications (NLEBA), Semiconductor Lab., Metallurgical \\ Lab. 2 Physics Department, Faculty of Education, Ain Shams University, Roxy, 11757 Cairo, Egypt \\ 7 Physics Department, Faculty of Women for Arts, Science, and Education, AinShams University, 11757, Cairo, Egypt \\ * Correspondence: medahmed6@yahoo.com;
}

Scopus Author ID 8641587100

Received: 22.04.2020; Revised: 25.05.2020; Accepted: 26.05.2020; Published: 1.06.2020

\begin{abstract}
A model molecule for $\mathrm{P}_{4} \mathrm{O}_{10}-\mathrm{ZnO}-\mathrm{CaO}$ is constructed to build Calcium Zinc Phosphate Oxide glasses. Then the effect of alkalis $\mathrm{Li}$; $\mathrm{Na}$ and $\mathrm{K}$ upon the model molecule is studied with $a b$ initio Hartree-Fockat HF/3-21G** level of theory. The overall aim is to evaluate the electronic properties of both the model molecules and alkali substituted molecules. The calculated parameters, including highest occupied molecular orbital/lowest unoccupied molecular orbital (HOMO/LUMO) bandgap energies; Total dipole moment (TDM) and molecular electrostatic potentials (MESP) are calculated. It has also been observed that the calculated TDM of the glassy system $\mathrm{P}_{4} \mathrm{O}_{10}-\mathrm{ZnO}-\mathrm{CaO}$ is increased while the $\mathrm{HOMOH/LUMO} \mathrm{band} \mathrm{gap} \mathrm{is} \mathrm{decreased} \mathrm{as} \mathrm{an} \mathrm{indication} \mathrm{for} \mathrm{the} \mathrm{reactivity} \mathrm{of} \mathrm{the} \mathrm{studied} \mathrm{model}$ molecules. The active sites for the studied models are described by the calculated MESP, which is confirming the results of both TDM and HOMO/LUMO.
\end{abstract}

Keywords: Phosphate glass; Nano metal oxides; Hartree-Fock; Alkali elements.

(c) 2020 by the authors. This article is an open-access article distributed under the terms and conditions of the Creative Commons Attribution (CC BY) license (https://creativecommons.org/licenses/by/4.0/).

\section{Introduction}

Many forms of glasses depend on their structure on phosphate glasses continue to be a topic for a variety of technological applications [1-3]. The molecular structure of phosphate glass shows different properties, which in turn dedicated to many different applications that are related to their molecular-level structures [4-6]. The addition of $\mathrm{ZnO}$ on phosphate glass affected the properties of phosphate glass [7-8]. Several studies were constructed on Calcium Zinc phosphate oxide glasses such as doping with $\mathrm{Mg}$ and $\mathrm{Li}$ [9-10]. Molecular modeling could be used alone and/or with the help of experimental molecular spectroscopic technique as a descriptive tool for the molecular structures of many systems and structures in different areas of science. Such computational techniques are now widely used to mimic the molecular behavior in chemistry, drug design, computational biology, and material science [11-16]. The 
range of molecular systems is ranging from small chemical systems to large biological molecules and material assemblies. It was previously utilized to study $\mathrm{P}_{4} \mathrm{O}_{10}-\mathrm{ZnO}-\mathrm{CaO}-\mathrm{Na} 2 \mathrm{O}$ glasses doped with copper oxide [17]. The temperature-dependent constraint model of alkali phosphate glasses was established for considering the structural and topological role of the modifying ion sub-network constituted by alkali ions and their non-bonding oxygen coordination spheres [18]. Molecular dynamics (MD) simulations have given new insight into the structural motifs which affect the dissolution, which is not accessible to experimental methods [19]. It is an excellent tool to describe atomic-level structural information for phosphate-based bioactive glasses [20]. MS simulations could also give information about the effect of alkali upon phosphate-based glasses [21-22]. Based on these considerations, it is clear that different classes of computational modeling gave information about the systems, whereas the experimental approach is limited or even unavailable [23-32]. Of course, glass systems are among these systems [33-34].

In this work, molecular modeling at HF/3-21G** is utilized to study the effect of Li$\mathrm{Na}-\mathrm{K}$ on Calcium Zinc Phosphate Oxide glasses.

\section{Materials and Methods}

All the studied structures are subjected to energy optimization, then some physical parameters are calculated. Total dipole moment and HOMO/LUMO bandgap energies and molecular electrostatic potential were calculated at a higher level of theory at HF/3-21G** using GAUSSIAN 09 software [35], which is implemented at Spectroscopy Department, National Research Centre, Egypt.

\section{Results and Discussion}

Before describing the results, it is important to describe how the model molecule is built. A model molecule of phosphate glass $\mathrm{P}_{4} \mathrm{O}_{10}$ is built as indicated in figure 1 , then $\mathrm{ZnO}$, $\mathrm{CaO}$ in the nanoscale are added as indicated in figure 2 . The metal oxides are added in the two of the three corners while in the last corner, as shown in figure $3, \mathrm{Li}, \mathrm{Na}, \mathrm{K}$ are added respectively; accordingly, $\mathrm{Li}, \mathrm{Na}, \mathrm{K}$ are added separately to form three models. Table 1 presented the calculated HF/3-21G** TDM and HOMO/LUMO band gap energy for the studied structures. Both physical quantities reflect the reactivity of a given compound. TDM is increased as the chemical reactivity increased. Meanwhile, decreasing the HOMO/LUMO band gap energy is also a descriptor for increasing the reactivity of a given chemical structure [][36-37]. For $\mathrm{P}_{4} \mathrm{O}_{10}$ structure, the TDM is 0.0000 Debye; the band gap was $12.3622 \mathrm{eV}$. For $\mathrm{P}_{4} \mathrm{O}_{10}-\mathrm{ZnO}-\mathrm{CaO}$ structure, the TDM is increased to 6.1981 Debye, and the bandgap energy is decreased to $3.5391 \mathrm{eV}$. This indicated that both metal oxides are increasing the reactivity of $\mathrm{P}_{4} \mathrm{O}_{10}$ structure. The effect of $\mathrm{Li}, \mathrm{Na}$, and $\mathrm{K}$ upon the reactivity of $\mathrm{P}_{4} \mathrm{O}_{10}-\mathrm{ZnO}-\mathrm{CaO}$ is also indicated in the same table. The TDM for $\mathrm{P}_{4} \mathrm{O}_{10}-\mathrm{ZnO}-\mathrm{CaO}-\mathrm{Li}$ is increased to be 23.5878 Debye; the bandgap energy is further decreased to be $1.4947 \mathrm{eV}$. The same quantities for $\mathrm{P}_{4} \mathrm{O}_{10}-\mathrm{ZnO}-\mathrm{CaO}-\mathrm{Na}$ are respectively 27.9715 Debye and $1.1715 \mathrm{eV}$. Finally, the TDM and bandgap energy became 27.8134 Debye, $2.0588 \mathrm{eV}$ corresponding to $\mathrm{P}_{4} \mathrm{O}_{10}-\mathrm{ZnO}-\mathrm{CaO}-\mathrm{K}$. Regarding these results, one can conclude that metal oxides in nanoscale such as $\mathrm{ZnO}$ and $\mathrm{CaO}$ increase the reactivity of $\mathrm{P}_{4} \mathrm{O}_{10}$. Further reactivity of such a system is achieved as far as easily ignitable elements are introduced to such a system. The ability of a given surface to interact with its surrounding medium is measured with another important physical quantity, which is 
the molecular electrostatic potential (MESP) that calculated at $\mathrm{HF} / 3-21 \mathrm{G}^{* *}$ level and indicated in Figures 1-c and 2-c. More specifically, MESP is displayed by charge distribution revolving around the molecule space. It is considered as an important parameter for understanding both the electrophilic and nucleophilic attacks sites for biological recognition [38]; this is, of course, for biological interactions process. More generally, it could be an indication of hydrogen bonding interactions [39] in material science. So that, the MESP is predicting the reactive molecular sites for the studied structures. The MESP map and contour are indicated by colors whereas, different values of the electrostatic potential at the surface are represented by different colors. Potential is following the increasing orders: red $<$ orange $<$ yellow $<$ green $<$ blue. Where blue indicates the highest electrostatic potential energy, and red indicates the lowest electrostatic potential energy ][40].Intermediary colors represent intermediary electrostatic potentials. They are introducing metal oxides as well as other metals, increasing the reactivity of the studied structure.

Table 1. Calculated HF/3-21G** total dipole moment and HOMO/LUMOband gap energy for the studied structures.

\begin{tabular}{lcc}
\hline \multicolumn{1}{c}{ Structure } & $\begin{array}{c}\text { Total dipole moment } \\
\text { Debye }\end{array}$ & $\begin{array}{c}\text { HOMO/LUMO } \\
\mathrm{eV}\end{array}$ \\
\hline $\mathrm{P}_{4} \mathrm{O}_{10}$ & 0.0000 & 12.3622 \\
$\mathrm{P}_{4} \mathrm{O}_{10}-\mathrm{ZnO}-\mathrm{CaO}$ & 6.1981 & 3.5391 \\
$\mathrm{P}_{4} \mathrm{O}_{10}-\mathrm{ZnO}-\mathrm{CaO}-\mathrm{Li}$ & 23.5878 & 1.4947 \\
$\mathrm{P}_{4} \mathrm{O}_{10}-\mathrm{ZnO}-\mathrm{CaO}-\mathrm{Na}$ & 27.9715 & 1.1715 \\
$\mathrm{P}_{4} \mathrm{O}_{10}-\mathrm{ZnO}-\mathrm{CaO}-\mathrm{K}$ & 27.8134 & 2.0588 \\
\hline
\end{tabular}
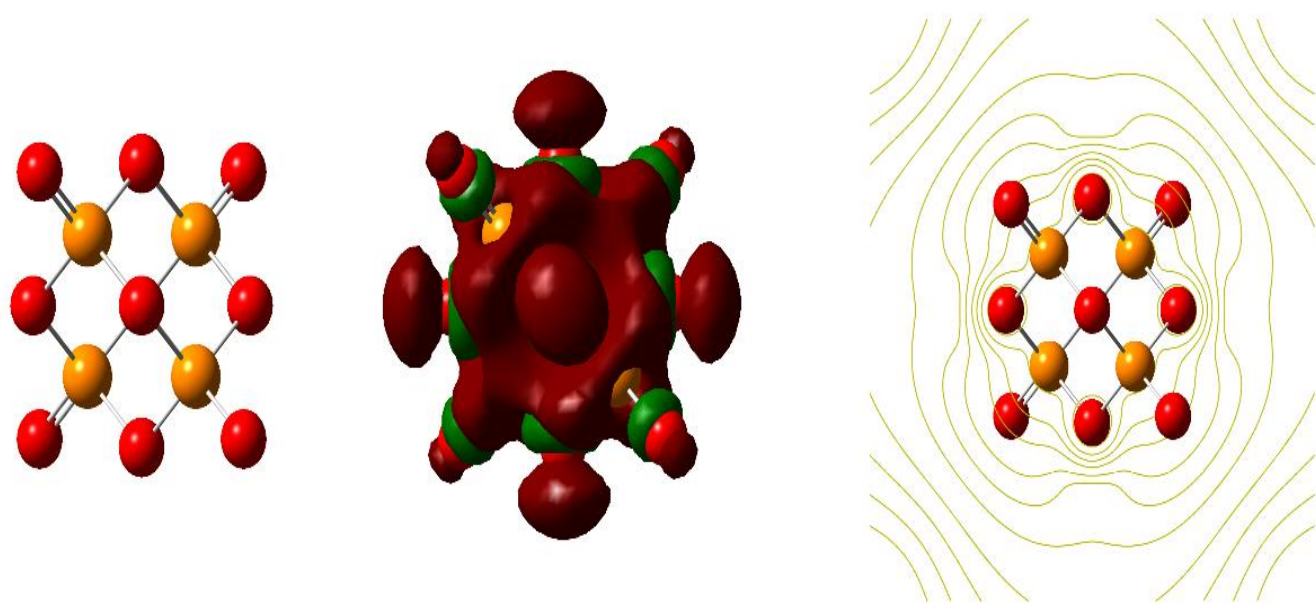

a

b c

Figure 1. HF/3-21G** calculated structures for a- $\mathrm{P}_{4} \mathrm{O}_{10}$, b- HOMO/LUMO for $\mathrm{P}_{4} \mathrm{O}_{10}$ and c- MESP for $\mathrm{P}_{4} \mathrm{O}_{10}$.

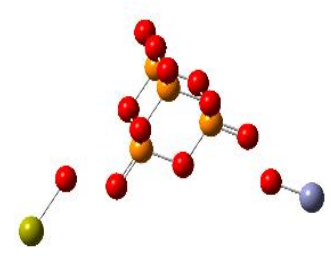

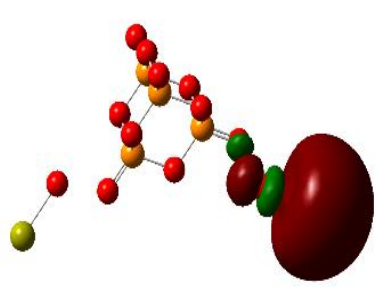

b

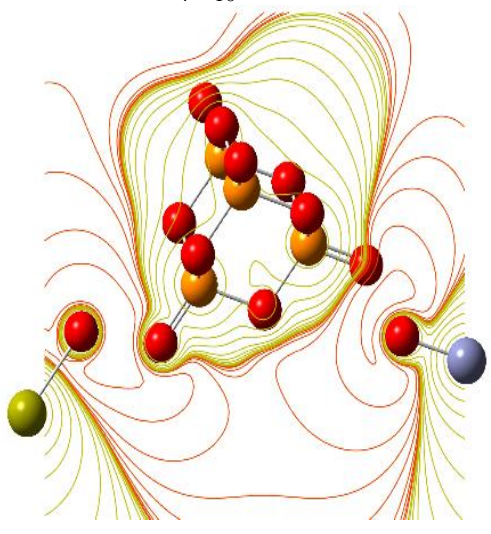

Figure 2. $\mathrm{HF} / 3-21 \mathrm{G} *$ * calculated structures for a- $\mathrm{P}_{4} \mathrm{O}_{10}-\mathrm{ZnO}-\mathrm{CaO}$, b- $\mathrm{HOMO} / \mathrm{LUMO}$ for $\mathrm{P}_{4} \mathrm{O}_{10}-\mathrm{ZnO}-\mathrm{CaO}$ and c- MESP for $\mathrm{P}_{4} \mathrm{O}_{10}-\mathrm{ZnO}-\mathrm{CaO}$. 


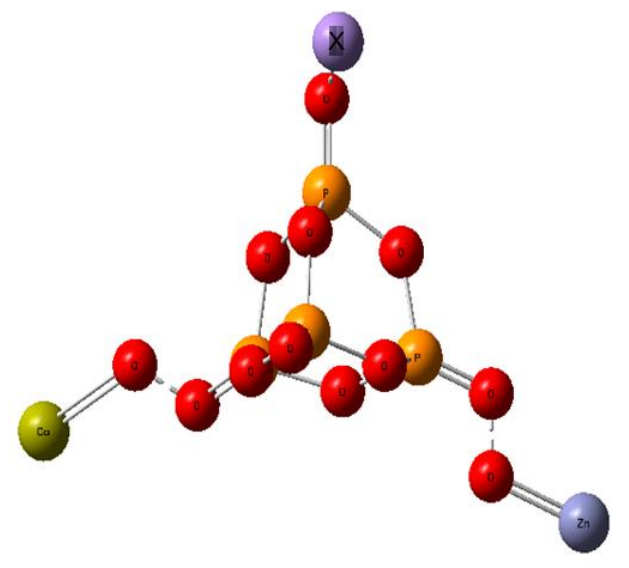

Figure 3. $\mathrm{HF} / 3-21 \mathrm{G}^{*} *$ calculated structures for $\mathrm{P}_{4} \mathrm{O}_{10}-\mathrm{ZnO}-\mathrm{CaO}-\mathrm{X}$; where $\mathrm{X}$ is $\mathrm{Li}$; $\mathrm{Na}$ and $\mathrm{K}$ respectively.

\section{Conclusions}

Molecular modeling, a cost-effective, safe, and easy-to-use tool helps to investigate, interpret, explain, and identify molecularly. properties of many systems and structures. In this work, it is applied at HF level to study the effect of alkali on the electronic properties of Phosphate $\left(\mathrm{P}_{4} \mathrm{O}_{10}\right)$ metal-oxide glass $(\mathrm{ZnO} \& \mathrm{CaO})$. TDM, HOMO/LUMO bandgap, and MESP are reflecting the reactivity of the studied structures. TDM is increased by decreasing the HOMO/LUMO bandgap as a result of doping. This is an indication that the studied metal oxides in nanoscale increase the reactivity of $\mathrm{P}_{4} \mathrm{O}_{10}$ glass. The calculated MESP indicted the active sites in the studied glass structure, which changes with changing the studied alkalis.

\section{Funding}

This research received no external funding.

\section{Acknowledgments}

The authors express their appreciation to "The Research Center for Advanced Materials Science (RCAMS)" at King Khalid University for funding this work under grant number RCAMS/KKU/016-20.

\section{Conflicts of Interest}

The authors declare no conflict of interest.

\section{References}

1. Brow, R.K. Review: the structure of simple phosphate glasses. Journal of Non-Crystalline Solids 2000, 263 264, 1-28, https://doi.org/10.1016/S0022-3093(99)00620-1.

2. Brow, R.K.; Kovacic, L.; Loehman, R.E. Novel Glass Sealing Technologies. Ceram. Trans. 1996, 177, 7088.

3. Day, D.E.; Wu, Z.; Ray, C.S.; Hrma, P. Chemically durable iron phosphate glass wasteforms. Journal of Non-Crystalline Solids 1998, 241, 1-12, https://doi.org/10.1016/S0022-3093(98)00759-5

4. Herms, G.; Sakowski, J.; Gerike, W.; Hoppe, U.; Stachel, D. Short-range and medium-range order in solid and molten metaphosphate glasses. Journal of Non-Crystalline Solids 1998, 232-234, 427-433, https://doi.org/10.1016/S0022-3093(98)00472-4.

5. Karabulut, M.; Melnik, E.; Stefan, R.; Marasinghe, G.K.; Ray, C.S.; Kurkjian, C.R.; Day, D.E. Mechanical and structural properties of phosphate glasses. Journal of Non-Crystalline Solids 2001, 288, 8-17, https://doi.org/10.1016/S0022-3093(01)00615-9. 
6. Goj, P.; Stoch, P. Molecular dynamics simulations of $\mathrm{P}_{2} \mathrm{O}_{5}-\mathrm{Fe}_{2} \mathrm{O}_{3}-\mathrm{FeO}-\mathrm{Na}_{2} \mathrm{O}$ glasses. Journal of NonCrystalline Solids 2018, 500, 70-77, https://doi.org/10.1016/j.jnoncrysol.2018.06.018.

7. Sułowska, J.; Wacławska, I.; Szumera, M. Comparative study of zinc addition effect on thermal properties of silicate and phosphate glasses. Journal of Thermal Analysis and Calorimetry 2016, 123, 1091-1098, https://doi.org/10.1007/s10973-015-5044-8.

8. Qaysi, M.A.; Petrie, A.; Shah, R.; Knowles, J.C. Degradation of zinc containing phosphate-based glass as a material for orthopedic tissue engineering. Journal of Materials Science: Materials in Medicine 2016, 27, 157, https://doi.org/10.1007/s10856-016-5770-x.

9. Wan, M.H.; Wong, P.S.; Hussin, R.; Lintang, H.O.; Endud, S. Physical and Optical Properties of Calcium Zinc Borophosphate Glasses Doped with Manganese Ions. Spectroscopy Letters 2015, 48, 473-480, https://doi.org/10.1080/00387010.2014.892512.

10. Koudelka, L.; Jirák, J.; Mošner, P.; Montagne, L.; Palavit, G. Study of lithium-zinc borophosphate glasses. Journal of Materials Science 2006, 41, 4636-4642, https://doi.org/10.1007/s10853-006-0031-x.

11. Youness, R.A.; Taha, M.A.; Elhaes, H.; Ibrahim, M. Molecular modeling, FTIR spectral characterization and mechanical properties of carbonated-hydroxyapatite prepared by mechanochemical synthesis. Materials Chemistry and Physics 2017, 190, 209-218, https://doi.org/10.1016/j.matchemphys.2017.01.004.

12. Galal, A.M.F.; Atta, D.; Abouelsayed, A.; Ibrahim, M.A.; Hanna, A.G. Configuration and molecular structure of 5-chloro-N-(4-sulfamoylbenzyl) salicylamide derivatives. Spectrochim Acta A 2019, 214, 476486, https://doi.org/10.1016/j.saa.2019.02.070.

13. Abdelsalam, H.; Teleb, N.H.; Yahia, I.S.; Zahran, H.Y.; Elhaes, H.; Ibrahim, M.A. First principles study of the adsorption of hydrated heavy metals on graphene quantum dots. Journal of Physics and Chemistry of Solids 2019, 130, 32-40, https://doi.org/10.1016/j.jpcs.2019.02.014.

14. Abdelsalam, H.; Saroka, V.A.; Ali, M.; Teleb, N.H.; Elhaes, H.; Ibrahim, M.A. Stability and electronic properties of edge functionalized silicene quantum dots: A first principles study. Physica E: Lowdimensional Systems and Nanostructures 2019, 108, 339-346, https://doi.org/10.1016/j.physe.2018.07.022.

15. Mahmoud, A.A.; Osman, O.; Elhaes, H.; Ferretti, M.; Fakhry, A.; Ibrahim, M.A. Computational Analyses for the Interaction Between Aspartic Acid and Iron. Journal of Computational and Theoretical Nanoscience 2018, 15, 470-473, https://doi.org/10.1166/jctn.2018.7113.

16. Abdel-Gawad, F.K.; Osman, O.; Bassem, S.M.; Nassar, H.F.; Temraz, T.A.; Elhaes, H.; Ibrahim, M. Spectroscopic analyses and genotoxicity of dioxins in the aquatic environment of Alexandria. Marine Pollution Bulletin 2018, 127, 618-625, https://doi.org/10.1016/j.marpolbul.2017.12.056.

17. Elhaes, H.; Attallah, M.; Elbashar, Y.; Al-Alousi, A.; El-Okr, M.; Ibrahim, M. Modeling and Optical Properties of $\mathrm{P}_{2} \mathrm{O}_{5}-\mathrm{ZnO}-\mathrm{CaO}-\mathrm{Na}_{2} \mathrm{O}$ Glasses Doped with Copper Oxide. Journal of Computational and Theoretical Nanoscience 2014, 11, 2079-2084, https://doi.org/10.1166/jctn.2014.3608.

18. Hermansen, C.; Mauro, J.C.; Yue, Y. A model for phosphate glass topology considering the modifying ion sub-network. The Journal of Chemical Physics 2014, 140, https://doi.org/10.1063/1.4870764.

19. Christie, J.K.; Ainsworth, R.I.; Di Tommaso, D.; de Leeuw, N.H. Nanoscale Chains Control the Solubility of Phosphate Glasses for Biomedical Applications. The Journal of Physical Chemistry B 2013, 117, 1065210657, https://doi.org/10.1021/jp4058115.

20. Christie, J.K.; Ainsworth, R.I.; Hernandez, S.E.R.; de Leeuw, N.H. Structures and properties of phosphatebased bioactive glasses from computer simulation: a review. Journal of Materials Chemistry B 2017, 5, 5297-5306, https://doi.org/10.1039/C7TB01236E.

21. Ainsworth, R.I.; Tommaso, D.D.; Christie, J.K.; de Leeuw, N.H. Polarizable force field development and molecular dynamics study of phosphate-based glasses. The Journal of Chemical Physics 2012, 137, https://doi.org/10.1063/1.4770295.

22. Di Tommaso, D.; Ainsworth, R.I.; Tang, E.; de Leeuw, N.H. Modelling the structural evolution of ternary phosphate glasses from melts to solid amorphous materials. Journal of Materials Chemistry B 2013, 1, 50545066, https://doi.org/10.1039/C3TB20662A.

23. Wang, J.; Li, B.; Zhang, X.; Hu, Q.; Yu, W.; Wang, H.; Duan, D.; Li, J.; Zhao, B. Docking and molecular dynamics studies on the mechanism of phospholipase D-mediated transphosphatidylation to construct the reaction kinetic model: Application in phosphatidylserine production. Journal of the Taiwan Institute of Chemical Engineers 2019, 96, 82-92, https://doi.org/10.1016/j.jtice.2018.12.012.

24. Liu, B.; Zhou, K. Recent progress on graphene-analogous $2 \mathrm{D}$ nanomaterials: Properties, modeling and $\begin{array}{llllll}\text { applications. } & \text { Progress in Materials } & \text { Science } & \text { 2019, } & \text { 100, }\end{array}$ https://doi.org/10.1016/j.pmatsci.2018.09.004.

25. Saleh, N.; Mostafa, A.A.; Omar, A.; Elhaes, H.; Ibrahim, M. Molecular Modeling Analyses of Modified Polyvinylalchol/Hydroxyapatite Composite. Journal of Computational and Theoretical Nanoscience 2017, 14, 2298-2301, https://doi.org/10.1166/jctn.2017.6823.

26. Ibrahim, A.; Elhaes. H.; Ibrahim, M.; Computational Notes on the Electronic Properties of Carboxylic Acid, Letters in Applied NanoBioScience. 2020, 9 (2), 1079-1082. https://doi.org/10.33263/LIANBS92.10791082

27. Ahmed, R.; Hanan, E.; Nabila, S.A.; Hanan, S.I.; Medhat, I. Green Route for the Removal of Pb from Aquatic Environment. Combinatorial Chemistry \& High Throughput Screening 2020, 23, 1-12, https://doi.org/10.2174/1386207323666200127123349. 
28. Bayoumy, A.M.; Refaat, A.; Yahia, I.S.; Zahran, H.Y.; Elhaes, H.; Ibrahim, M.A.; Shkir, M. Functionalization of graphene quantum dots (GQDs) with chitosan biopolymer for biophysical applications. Optical and Quantum Electronics 2019, 52, 5986-5993. https://doi.org/10.1007/s11082-019-2134-z.

29. Macias-Jamaica, R.E.; Castrejón-González, E.O.; González-Alatorre, G.; Alvarado, J.F.J.; Díaz-Ovalle, C.O. Molecular models for Sodium Dodecyl Sulphate in aqueous solution to reduce the micelle time formation in molecular simulation. Journal of Molecular Liquids 2019, 274, 90-97, https://doi.org/10.1016/j.molliq.2018.10.121.

30. Abdel-Karim, A. Elhaes. H.; El-Kalliny. A. S.; Badawy, M. I.; Ibrahim, M.; Gad-Allah, T.G. Probing Protein rejection behavior of blended PES-based flat-sheet ultrafiltration membranes: A density functional theory (DFT) study, Spectrochimica Acta A 2020, 238. 118399. https://doi.org/10.1016/j.saa.2020.118399

31. Badry, R.; El-Khodary, S.; Elhaes, H.; Nada, N.; Ibrahim, M. On the molecular modeling analyses of sodium carboxymethyl cellulose treated with acetic acid. Letters in Applied NanoBioScience 2019, 8, 553557, https://doi.org/10.33263/LIANBS 82.553557 .

32. El-Mansy. M. A. M.; Osman, O.; Mahmoud, A-A.; Elhaes, H.; Ibrahim, M.; Computational Notes on the Molecular Modeling Analyses of Flutamide, Letters in Applied NanoBioScience 2020, 9 (2), 1099-1102. https://doi.org/10.33263/LIANBS92.10991102

33. Selim, A.Q.; Sellaoui, L.; Mobarak, M. Statistical physics modeling of phosphate adsorption onto chemically modified carbonaceous clay. Journal of Molecular Liquids 2019, 279, 94-107, https://doi.org/10.1016/j.molliq.2019.01.100.

34. Donnini, J.; Chiappini, G.; Lancioni, G.; Corinaldesi, V. Tensile behaviour of glass FRCM systems with fabrics' overlap: Experimental results and numerical modeling. Composite Structures 2019, 212, 398-411, https://doi.org/10.1016/j.compstruct.2019.01.053.

35. Gaussian 09, Revision C.01,M. J. Frisch, G. W. Trucks, H. B. Schlegel, G. E. Scuseria ,M. A. Robb, J. R. Cheeseman, G. Scalmani, V. Barone, B. Mennucci, G. A. Petersson, H. Nakatsuji, M. Caricato, X. Li, H. P. Hratchian, A. F. Izmaylov, J. Bloino, G. Zheng, J. L. Sonnenberg, M. Hada ,M. Ehara, K. Toyota, R. Fukuda, J. Hasegawa, M. Ishida, T. Nakajima, Y. Honda, O. Kitao, H. Nakai, T. Vreven, J. A. Montgomery, Jr ,.J. E. Peralta, F. Ogliaro, M. Bearpark, J. J. Heyd, E. Brothers ,K. N. Kudin, V. N. Staroverov, T. Keith, R. Kobayashi, J. Normand ,K. aghavachari, A. Rendell, J. C. Burant, S. S. Iyengar, J. Tomasi ,M. Cossi, N. Rega, J. M. Millam, M. Klene, J. E. Knox, J. B. Cross ,V. Bakken, C. Adamo, J. Jaramillo, R. Gomperts, R. E. Stratmann ,O. Yazyev, A. J. Austin, R. Cammi, C. Pomelli, J. W. Ochterski ,R. L. Martin, K. Morokuma, V. G. Zakrzewski, G. A. Voth, P. Salvador, J. J. Dannenberg, S. Dapprich, A. D. Daniels ,O. Farkas, J. B. Foresman, J. V. Ortiz, J. Cioslowski ,and D. J. Fox, Gaussian, Inc., Wallingford CT 2010.

36. brahim, M.; Elhaes, H. Computational Spectroscopic Study of Copper, Cadmium, Lead and Zinc Interactions in the Environment. Int. J. Environment and Pollution 2005, 23, 417-424, https://doi.org/10.1504/IJEP.2005.007604.

37. brahim, M.; Mahmoud, A.A. Computational Notes on the Reactivity of Some Functional Groups. Journal of Computational and Theoretical Nanoscience 2009, 6, 1523-1526, https://doi.org/10.1166/jctn.2009.1205.

38. Politzer, P.; Laurence, P.R.; Jayasuriya, K. Molecular electrostatic potentials: an effective tool for the elucidation of biochemical phenomena. Environ Health Perspect 1985, 61, 191-202, https://doi.org/10.1289/ehp.8561191.

39. Politzer, P.; Murray, J.S. Relationships of Electrostatic Potentials to Intrinsic Molecular Properties, J.Theor.Comput.Chem. 1996, 3, 649-660, https://doi.org/10.1016/S1380-7323(96)80056-2.

40. Şahin, Z.S.; Şenöz, H.; Tezcan, H.; Büyükgüngör, O. Synthesis, spectral analysis, structural elucidation and quantum chemical studies of (E)-methyl-4-[(2-phenylhydrazono)methyl]benzoate. Spectrochimica Acta Part A 2015, 143, 91-100, https://doi.org/10.1016/j.saa.2015.02.032. 